\title{
Chaya (Jatropha tanjorensis) leafs protect against sodium benzoate mediated renal dysfunction and hepatic damage in rats
}

\author{
Johnson Olaleye Oladele ${ }^{1 *}$, Oluwaseun Titilope Oladele ${ }^{2}$, Adedayo Oluwaseun Ademiluyi ${ }^{3}$, \\ Oyedotun Moses Oyeleke ${ }^{1,2}$, Olaide Oladimeji Awosanya ${ }^{1}$ and Olu Israel Oyewole ${ }^{2}$
}

\begin{abstract}
Background: Jatropha tanjorensis is a commonly consumed green leafy plant that has found usage in folk medicine. Sodium benzoate $\left(\mathrm{C}_{6} \mathrm{H}_{5} \mathrm{COONa}\right)$ is a widely used preservative in food/drink industries with potential cytotoxicity. Protective effect of some leafy plants on xenobiotic-induced toxicity have been established. Hence, this study sought to investigate the protective effect of methanolic leaf extract of Jatropha tanjorensis on sodium benzoate mediated renal and hepatic dysfunction in rats.

Results: Sodium benzoate treatment caused significant $(P<0.05)$ alteration in kidney (serum urea, uric acid, and creatinine) and liver (aspartate and alanine transaminases, acid and alkaline phosphatases) damage markers, serum albumin, globulin and total protein levels as well as cellular architecture which were significantly reversed in groups treated with the leaf extracts. Phytochemical screening of the leaf extract revealed the presence of terpenoids, saponins, cardiac glycosides, flavonoids and tannins.
\end{abstract}

Conclusion: Sodium benzoate-induced alterations in the renal and hepatic indices were mitigated following treatment with $J$. tanjorensis leaf extracts which suggests protective effect of the extract against sodium benzoate intoxication.

Keywords: Hepatocellular damage, Renal dysfunction, Phytochemical constituents, Jatropha tanjorensis, Sodium benzoate

\section{Background}

Jatropha tanjorensis belongs to the family Euphorbiaceae; a common weed of field crops and a gregarious shrub of about $1.8 \mathrm{~m}$ in height. It is usually grown in rainfall forest zones of West Africa. Jatropha is known for its use as purgative/laxative and other medicinal purposes. All parts of the plant including seeds, leaves and bark; fresh or as a decoction, are used in traditional and folk medicine as well as veterinary purposes [13]. In some parts of Nigeria, the leaf of J. tanjorensis are locally

\footnotetext{
* Correspondence: jo.oladele@kingsuniversity.edu.ng;

oladelejohn2007@gmail.com; ademiluyidayo@yahoo.co.uk

'Department of Chemical Sciences, Faculty of Science, Kings University,

Ode-Omu, Nigeria

Full list of author information is available at the end of the article
}

consumed as vegetable added to daily meal as well as in treating diabetes mellitus due to its anti-hyperglycemic property [26]. The antioxidant and hypoglyceamic properties of the leaf extracts makes it a popular remedy for the treatment of diabetics, malaria and hypertension in these regions.

Many scientific evidences abund on the medicinal properties of this plant. Leaf extract of $J$. tanjorensis have been reported to contain phytochemical constituents capable of lowering blood cholesterol level which is useful in the treatment of cardiovascular diseases caused by hyperlipidemia [31]. Its antibacterial activities have been shown by Iwalewa et al. [20]. Earlier reports have shown that $J$. tanjorensis is rich in antioxidant nutrients like phosphorus, selenium, zinc and vitamins $\mathrm{C}$ and $\mathrm{E}$ [27]. 
Administration of the leaf powder to rabbits resulted in improvement in hematological indices which revealed an enhancement of bone marrow function [28]. Furthermore, antioxidant properties of free and bound phenolic extract of the leaf have been reported [1].

Sodium benzoate is a colourless crystalline salt used as preservatives in beverages, fruit products, chemically leavened baked goods, and condiments [11, 38]. Benzoic acid and sodium benzoate are used as antimicrobial agents in edible coatings. Sodium benzoate is also found useful in pharmaceuticals as therapeutic regimens in the treatment of patients with urea cycle enzymopathies and for preservation purposes in liquid medicines. It is also employed as an anticorrosive particularly, as additive to automotive engine antifreeze coolants and waterborne systems [2, 38]. However, despite its popular application, acute toxicity such as urticarial, asthma, rhinitis, or anaphylactic shock have been reported following exposure to this compound. Sodium benzoate was mutagenic and cytotoxic in lymphocytes with micronucleus formation and chromosome breakage [34].

Nevertheless, sodium benzoate is widely used as food preservative and in various products which influenced its degree of exposure as well as its toxicity. Hence, there is need for novel strategies towards mitigating toxic effects arising from human exposure to this compound. This study thus sought to evaluate the protective effect of methanolic leaf extract of Jatropha tanjorensis on sodium benzoate-induced toxicity in rats.

\section{Materials and methods Materials}

Urea, uric acid, creatinine, and enzyme diagnostic kits (ALT, AST, ALP and ACP) were obtained from Randox Laboratories Limited, United Kingdom. Sodium benzoate salt is a product of May and Baker Ltd. Dagenham, England. All other chemicals which are products of Sigma Chemical Company, St Louis, USA were of analytical grade and were prepared in the laboratory in double glass distilled water.

\section{Collection of plant material and preparation of extracts} Fresh samples of Jatropha tanjorensis leaves were collected at a farm settlement, at Osogbo, Nigeria. The plant was identified at the Botany Unit, Department of Biological Sciences, Osun State University, Osogbo. Dried sample of the leaves was deposited at the University herbarium for future reference. The leaves were airdried to constant weight at room temperature after which they were pulverized. The leaf powder was homogenized in 6 volumes of $80 \%$ methanol for $72 \mathrm{~h}$ after which it was filtered through a Whatman filter paper. The crude extract was recovered following removal of the solvent on a water bath. The concentrated extract was allowed to dry at room temperature after which serial dilution of the extract was prepared.

\section{Phytochemical screening}

Phytochemical tests were carried out on the aqueous extracts of the sample using standard procedures as described by Harborne [16]. The total phenol content was determined according to Singleton et al. [36] while total flavonoid content was determined according to Meda et al. [23].

\section{Experimental animals}

Twenty-four male Wistar albino rats weighing between 160 and $170 \mathrm{~g}$ used for the experiment were obtained and raised at the Central Animal House, Osun State University, Osogbo, Nigeria. The rats were kept in ventilated cage at optimum temperature and $12 \mathrm{~h}$ light / dark cycle and fed with commercial grower smash and water ad libitum. The study was carried out in accordance with established guidelines on the care of laboratory animals following approval by the Institution's Ethical Committee. The rats were acclimatized for 2 weeks before administration commenced.

\section{Experimental design and dose administration}

The rats were sorted into four (4) different groups containing six (6) rats each as follows;

Control: Animals were given distilled water only;

SBT: Animals were treated with oral administration of sodium benzoate $(200 \mathrm{mg} / \mathrm{kg}$ bw) only;

SBT + JG1: Animals were given sodium benzoate (200 $\mathrm{mg} / \mathrm{kg} \mathrm{bw})+J$. tanjorensis extract $(200 \mathrm{mg} / \mathrm{kg} \mathrm{b.w})$; and.

SBT + JG2: Animals were given sodium benzoate (200 $\mathrm{mg} / \mathrm{kg} \mathrm{bw})+J$. tanjorensis extract $(500 \mathrm{mg} / \mathrm{kg}$ b.w).

The animals were maintained on this treatment regime throughout the 14-day duration of the study. Average body weight of each group were taken and recorded daily. The chosen doses for this experiment was based on method of Oyewole et al. [33] and administration of extract was done using oral gavage.

\section{Preparation of serum}

The rats were weighed and sacrificed $24 \mathrm{~h}$ following the last treatment by cervical dislocation. The jugular vein was punctured by needle and blood collected in to plain bottles. The blood was allowed to clot and centrifuged at $4000 \mathrm{rpm}$ for $30 \mathrm{~min}$ to obtain the serum. The serum obtained was stored in a refrigerator at $4{ }^{\circ} \mathrm{C}$ for biochemical analysis.

\section{Preparation of tissue homogenates}

The animals were quickly dissected and tissues (liver and kidney) immediately excised, rinsed with $\mathrm{KCl}$, blotted with filter paper and weighed. They were then chopped into bits and homogenized in 4 volumes of 0.1 $\mathrm{M}$ Tris- $\mathrm{KCl}$ ( $\mathrm{pH}$ 7.4) using a Teflon homogenizer. The resulting homogenate was centrifuged at $12,500 \mathrm{~g}$ for 15 
min in a cold centrifuge $\left(-4^{\circ} \mathrm{C}\right)$ to obtain the post mitochondrial fraction. The supernatant was collected and used for biochemical analyses.

\section{Estimation of biochemical parameters}

Uric acid was estimated in the serum according to the method of Cheesbrough [8]. Serum creatinine and urea were determined as described by Cheesbrough [9]. The bromocresol green method described by Cheesbrough [8] was used to determine albumin concentration. Serum globulin was estimated using the procedure of Mokady et al. [24]. Protein concentration was determined in the serum by the method of Lowry et al. [22] using bovine serum albumin as standard. Aspartate amino transferase (AST) and aspartate amino transferase (ALT) activities were determined in the serum using Randox diagnostic kits based on the principle described by Reitman and Frankel [35]. Alkaline phosphatase (ALP) and acid phosphatase (ACP) were determined in the serum using commercially available enzymatic test kits (Randox Laboratory Ltd., UK) following the manufacturer's instructions.

\section{Histological examination}

The liver and kidney tissues were immediately fixed in $10 \%$ formalin and embedded in paraffin wax. Fine sections (7-9 $\mathrm{mm}$ thickness) of the tissues were then dewaxed in xylene, hydrated in decreasing percentage of alcohol and stained with hematoxylin and eosin. The stained sections were observed under a Leitz microscope and their photomicrograph taken at $\times 100$ with a Canon (Meville, NY) Power Shot G2 Digital Camera.

\section{Statistical analysis}

Results obtained were presented as mean \pm SD. Variation within a set of data was analyzed by one-way analysis of variance (ANOVA) using the Graph Pad Prism Software (GPPS). Values of $p<0.05$ were taken as statistically significant.

\section{Results}

The phytochemical screening of the methanolic leaf extract revealed the presence of saponins, flavonoids, cardiac glycosides, tannins and terpenoids as constituent phytochemicals of the $J$. tanjorensis leaf. However, as depicted in Table 1, the total phenol content of the extract is $142.23 \mathrm{mg} / \mathrm{g}$ Gallic acid equivalent while the total flavonoid content is $89.15 \mathrm{mg} / \mathrm{g}$ Catechin equivalent.

Figure 1 revealed the effect of methanolic leaf extract of Jatropha tanjorensis on sodium benzoate mediated alteration in serum renal metabolites in experimental rats. It was demonstrated in the study that exposure of rats to sodium benzoate resulted into renal damage as shown by significant $(P<0.05)$ increase in the serum renal metabolites: urea, uric acid and creatinine when compared
Table 1 The total phenol and total flavonoid contents of the methanolic extract of Jatropha tanjorensis leaves

\begin{tabular}{ll}
\hline Phytochemical & Levels \\
\hline Total phenol & $142.23 \pm 18.81$ \\
Total flavonoid & $89.15 \pm 9.93$ \\
\hline
\end{tabular}

Values represent mean \pm standard deviation of triplicate $(n=3)$ experiments

to the control group. However, treatment with the leaf extracts significantly $(P<0.05)$ reversed these alterations in the serum markers of kidney damage in a dosedependent manner.

Serum activities of ALP and ACP were significantly elevated $(P<0.05)$ in treated groups following exposure to sodium benzoate when compared with the control group (Fig. 2). However, administration of methanolic leaf extract of $J$. tanjorensis caused a marked reversal in the activities of these enzymes dose-dependently.

Figure 3 reflects the effect of the leaf extract of $J$. tanjorensis on sodium benzoate-induced alteration in serum transaminase activities. The results reveal that exposure to sodium benzoate causes a significant $(P<0.05)$ increase in serum ALT and AST activities when compared to the control groups. Nevertheless, the activities of the transaminases (ALT and AST) were significantly $(P<0.05)$ reduced following treatment with the leaf extract of $J$. tanjorensis in a dose-dependent manner.

The effect of methanolic leaf extract of $J$. tanjorensis on sodium benzoate mediated alteration in serum protein (albumin and globulin) levels in experimental rats is presented in Fig. 4. The result showed a significant $(P<$ 0.05 ) reduction in both serum albumin and globulin levels following daily oral exposure to sodium benzoate when compared to the control group. However, treatment with the leaf extract restored serum protein to levels comparable to control group.

Figure 5 depicts the result obtained from the histological examination of sections of liver and kidneys slices from the animals. The result revealed no significant alteration in the morphological presentation of the hepatic tissue in the control group as well as the sodium benzoate intoxicated groups treated with the J. tanjorensis leaf extract. This was accompanied by a well outlined cellular profile and distinct hepatic structure. However, the group treated with sodium benzoate only was characterized by a mild loss of liver parenchyma, deranged cellular profiles, hemorrhage and presence of inflammatory red cells within and around the central vein including the sinusoids as well as distorted hepatic vessels (black arrow). Furthermore, no marked degenerative changes was seen in the kidney slices of the control group as well as the sodium benzoate intoxicated group treated with $500 \mathrm{mg} / \mathrm{kg}$ body weight of the leaf extract. However, mild focal sclerosis of the glomerulus, widening of the Bowman's space and hyper cellularity are all observable across groups treated with sodium benzoate alone and the 


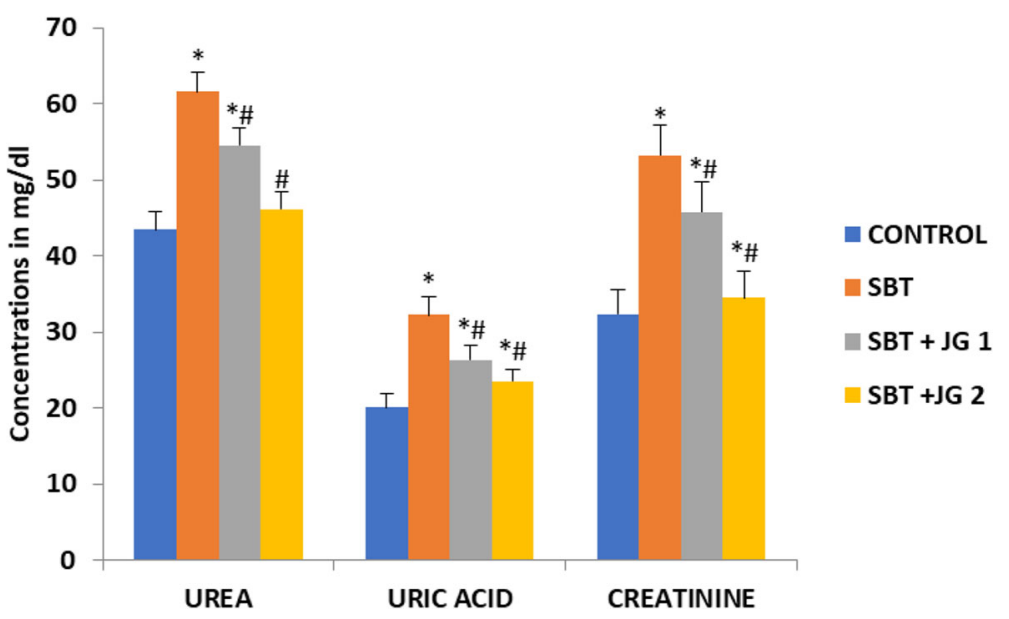

Fig. 1 The effect of methanolic leaf extract of Jatropha tanjorensis on sodium benzoate mediated alteration in serum renal metabolites in experimental rats. Data presented as Mean \pm standard deviation $(n=6)$. ${ }^{*}$ Significantly different from normal control group at $P<0.05$, ${ }^{\#}$ significantly different from group SBT at $P<0.05$. Control: Animals were given distilled water only; SBT: Animals were treated with oral administration of sodium benzoate $(200 \mathrm{mg} / \mathrm{kg}$ bw) only; SBT + JG1: Animals were given sodium benzoate $(200 \mathrm{mg} / \mathrm{kg}$ bw $)+J$. tanjorensis extract (200 mg/kg b.w); and SBT + JG2: Animals were given sodium benzoate (200 mg/kg bw) + J. tanjorensis extract (500 mg/kg b.w)

group treated with $200 \mathrm{mg} / \mathrm{kg}$ body weight of the leaf extract. Sodium benzoate alone treated group, further displayed mild fibrosis and hemorrhage that was characterized by the presence of red inflammatory cells (arrow).

\section{Discussion}

This study investigated the protective potentials of Jatropha tanjorensis leaf extract against sodium benzoate $\left(\mathrm{C}_{6} \mathrm{H}_{5} \mathrm{COONa}\right)$-mediated hepato-renal toxicity in wistar rats. The observed increase in kidney damage markers (urea, uric acid and creatinine) are indication of renal toxicity. These markers are important metabolites for routine clinical assessment of renal function. Increase in serum urea has been reported in acute and chronic intrinsic renal disease [6] and in decreased effective circulating blood volume with impaired renal perfusion [29]. Increase in serum creatinine has also been reported to arise from intrinsic renal lesions, decreased renal perfusion, or obstruction of lower urinary tract [3]. However, the improved renal function following treatment with the leaf extract is suggestive of protective effect of the $J$. tanjorensis on the kidney. This result is in tandem with

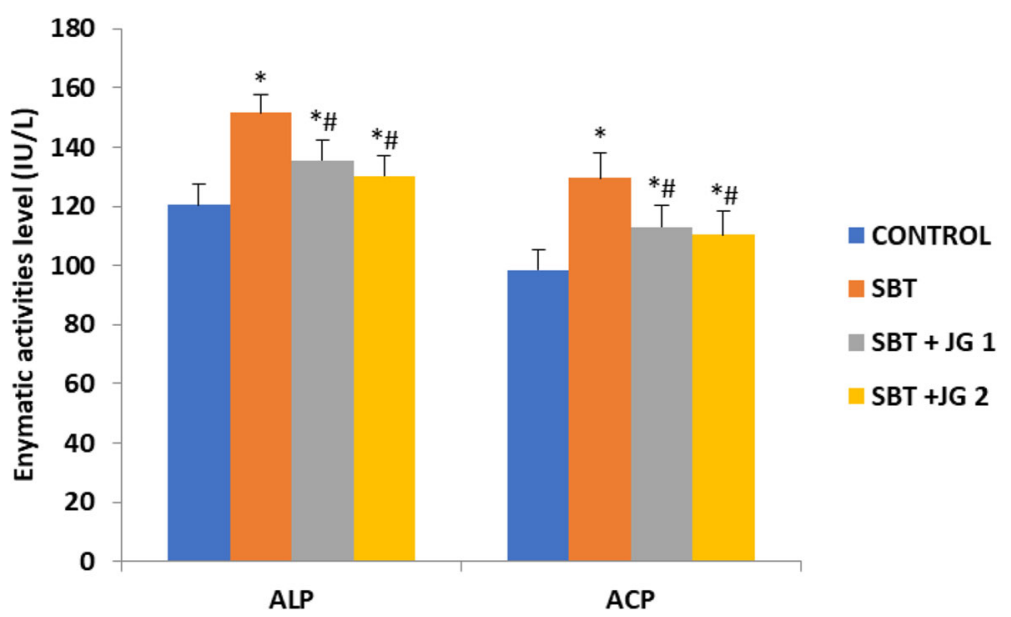

Fig. 2 The effect of methanolic leaf extract of Jatropha tanjorensis on sodium benzoate mediated alteration in serum ALP and ACP in experimental rats. Data presented as Mean \pm standard deviation $(n=6)$. ${ }^{*}$ Significantly different from normal control group at $P<0.05$, \# significantly different from group SBT at $P<0.05$. Control: Animals were given distilled water only; SBT: Animals were treated with oral administration of sodium benzoate (200 mg/kg bw) only; SBT + JG1: Animals were given sodium benzoate $(200 \mathrm{mg} / \mathrm{kg}$ bw) + J. tanjorensis extract (200 mg/kg b.w); and SBT + JG2: Animals were given sodium benzoate (200 mg/kg bw) + J. tanjorensis extract (500 mg/kg b.w) 


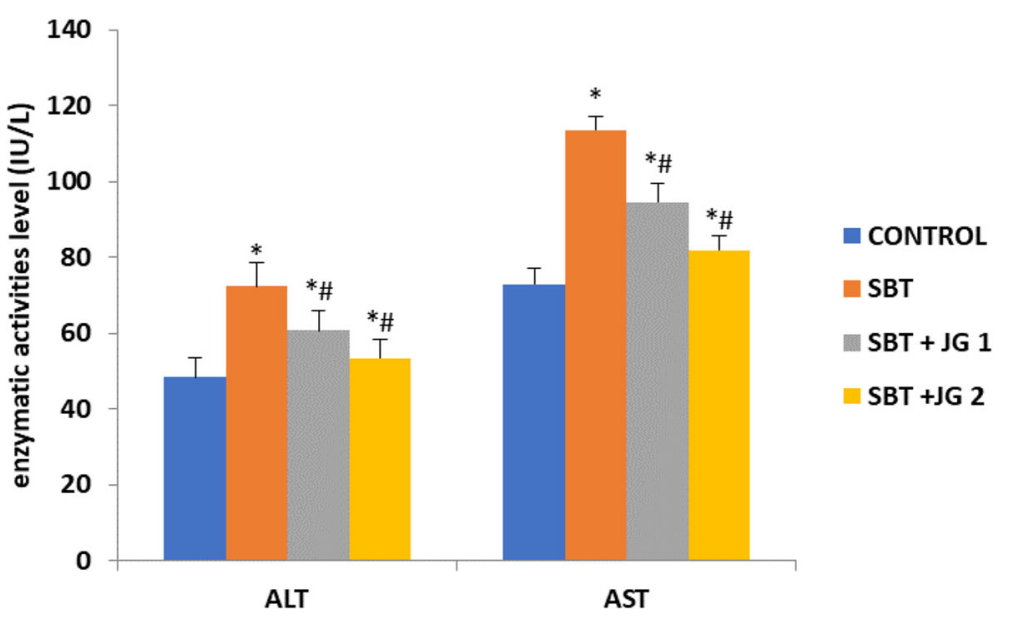

Fig. 3 The effect of methanolic leaf extract of Jatropha tanjorensis on sodium benzoate mediated alteration in serum ALT and AST in experimental rats. Data presented as Mean \pm standard deviation $(n=6)$. *Significantly different from normal control group at $P<0.05$, \# significantly different from group SBT at $P<0.05$. Control: Animals were given distilled water only; SBT: Animals were treated with oral administration of sodium benzoate $(200 \mathrm{mg} / \mathrm{kg} \mathrm{bw})$ only; SBT + JG1: Animals were given sodium benzoate $(200 \mathrm{mg} / \mathrm{kg}$ bw) + J. tanjorensis extract (200 mg/kg b.w); and SBT + JG2: Animals were given sodium benzoate (200 mg/kg bw) + J. tanjorensis extract (500 mg/kg b.w)

the report of Oyewole et al. [33] on the same plant leaf. However, the ameliorative effect of the leaf extracts on kidney function could be attributed to constituent phytochemicals such as terpenoids [12], saponins [10], flavonoids [15] and tannins with known renoprotective properties. Saponins are potent modulator of the renin-angiotensin-aldosterone system (RAAS), critical to kidney function. Saponin was reported to exert renoprotective effect via inhibition of intrarenal RAAS. Flavonoids could confer renoprotection against glomerulonephritis, diabetic nephropathy, and chemicallyinduced kidney insufficiency [15].
ALP and ACP are marker enzymes for plasma membrane stability and are required for proper functioning of the liver $[5,40]$. These enzymes are critical in clinical and toxicological studies as changes in their activities could indicate tissue damage or disease. Exposure to chemical substances such as sodium benzoate may result in changes in structural architecture and impaired metabolism/biochemical events within the cells leading to altered physiological conditions [25]. Thus, increased serum activities of the enzyme is suggestive of sodium benzoate-induced tissue damage. Nevertheless, the reduction in their activities following

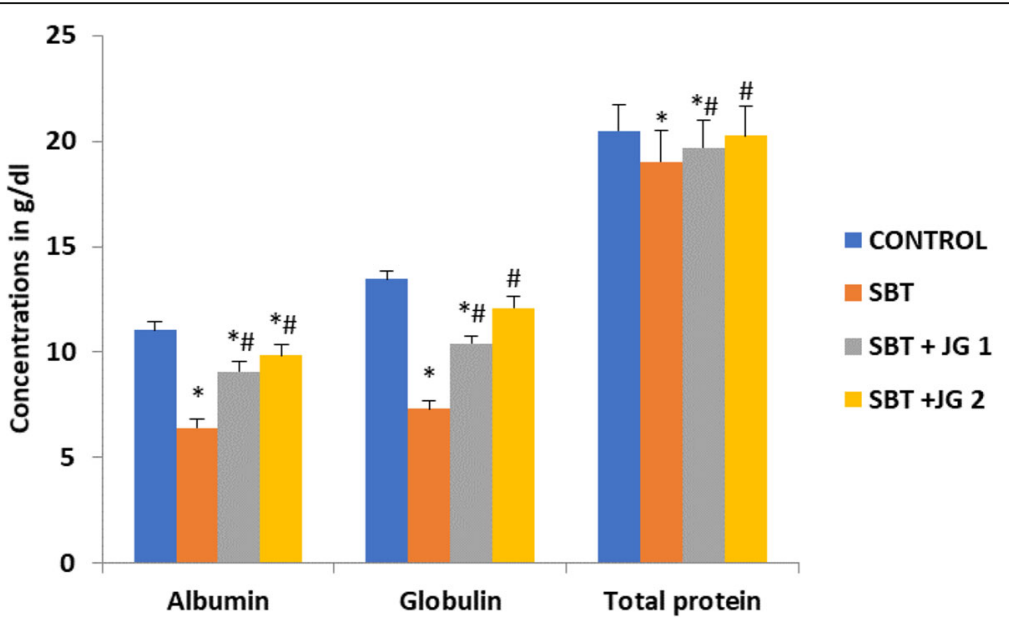

Fig. 4 The effect of methanolic leaf extract of Jatropha tanjorensis on sodium benzoate mediated alteration in serum protein levels in experimental rats. Data presented as Mean \pm standard deviation $(n=6)$. * Significantly different from normal control group at $P<0.05$, \# significantly different from group SBT at $P<0.05$. Control: Animals were given distilled water only; SBT: Animals were treated with oral administration of sodium benzoate $(200 \mathrm{mg} / \mathrm{kg} \mathrm{bw})$ only; SBT $+\mathrm{JG1}$ : Animals were given sodium benzoate $(200 \mathrm{mg} / \mathrm{kg}$ bw) $+J$. tanjorensis extract (200 mg/kg b.w); and SBT + JG2: Animals were given sodium benzoate (200 mg/kg bw) + J. tanjorensis extract (500 mg/kg b.w) 


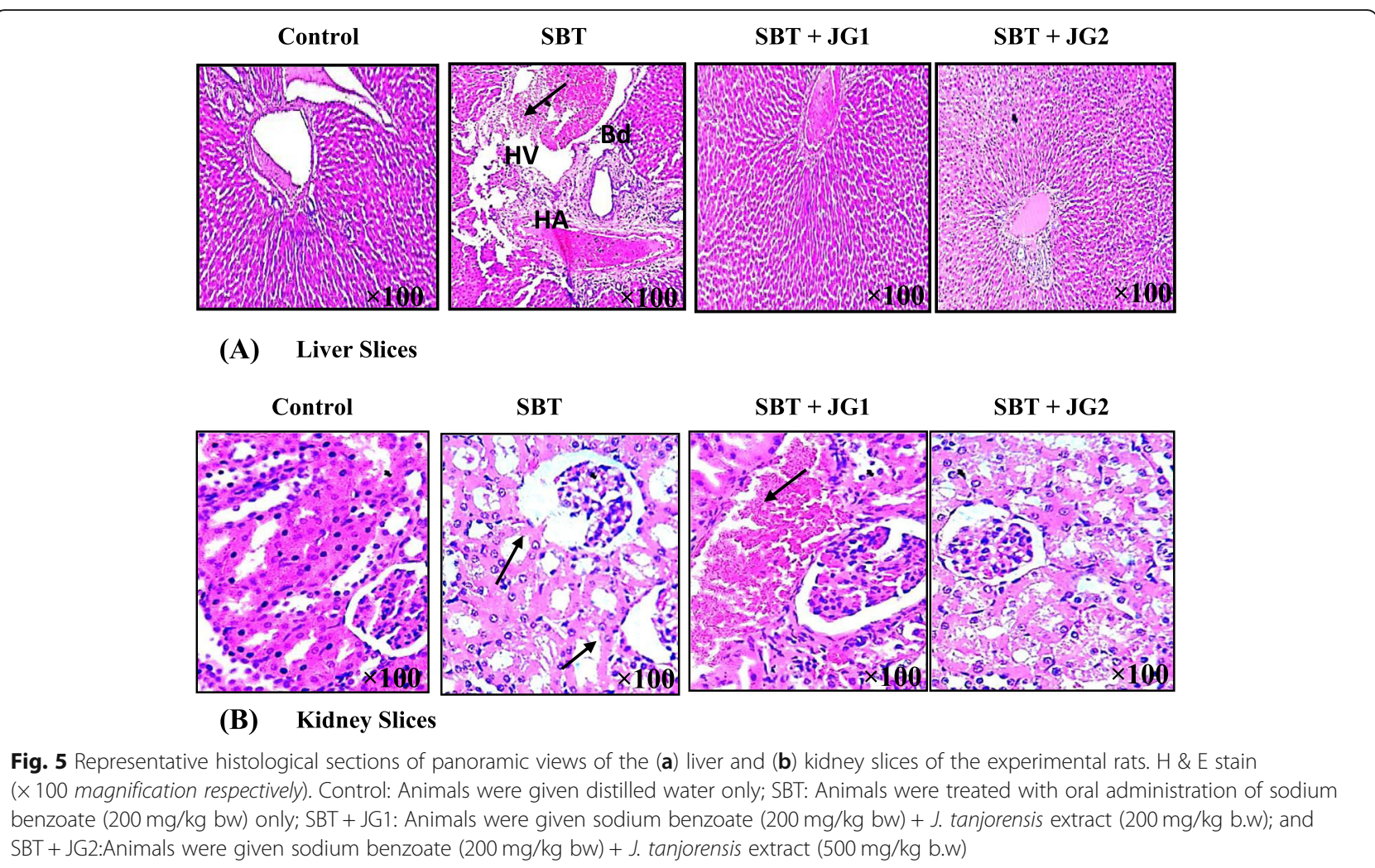

treatment with $J$. tranjorensis extract in groups exposed to sodium benzoate could be due to the ameliorative properties of its phytoconstituents such as flavonoids which protect against cellular damage via inhibition of membrane lipid peroxidation and alteration in critical tissue biomolecules. Furthermore, flavonoids have been reported to inhibit phosphatases [18]. Hence, the observed decrease in ALP and ACP activities following treatment with the leaf extract could be due to flavonoid-induced inhibition.

The observed increase in serum transaminases (AST and ALT) suggests hepatocellular injury in rats exposed to sodium benzoate. These enzymes are critical to clinical diagnosis of hepatocellular injury as well as health status of the liver; with increased serum activities of the enzymes indicative of liver injury. Thus, increase in serum AST and ALT activities following sodium benzoate intoxication suggests leakage of the cytosolic enzymes into the blood stream due to increased lipid peroxidation and damage to cellular membrane. This finding agreed with previous reports on some xenobiotic-induced liver damage in mammalian models [7, 32]. However, reduction in the enzyme activities following treatment with the leaf extract of $J$. tanjorensis is suggestive of hepatoprotection or restoration of normal cellular activities by its constituent phytochemicals. Hepatoprotective property of many plant foods/materials have been previously documented.
Protein synthesis was compromised in the sodium benzoate-treated animals as evidenced by reduced serum albumin and globulin levels. Liver is the main organ responsible for protein synthesis and maintenance of protein homeostasis. Hence, liver injury would result in impaired protein synthesis. Thus, the reduced serum total protein level following sodium benzoate exposure could be due to liver damage or impaired hepatic function. Cytotoxic effect of sodium benzoate in primary culture of rat hepatocytes was shown to occur via suppression of intracellular protein and DNA synthesis [30]. Nevertheless, the observed increased in the serum protein levels following $J$. tanjorensis treatment suggest restoration of hepatic function, stimulation of protein synthesis and/or protection against sodium benzoate-impaired protein synthesis by constituent phytochemicals of J. tanjorensis leaves.

Sodium benzoate caused marked derangement in cellular architecture and triggered inflammatory response in the liver and kidneys of the intoxicated rats as observed from the histological studies. However, this was abrogated by treatment with $J$. tanjorensis leaf extract which reinforces its cytoprotective property. The protective effect of the leaf extract could be mediated via regulation of sodium benzoate-induced derangement in cellular antioxidant and inflammatory responses. Studies have shown that components of plant foods/extracts rich in bioactive compounds such as polyphenols could modulate 
antioxidant response by activating the transcription factor Nrf2 [4, 19, 37, 39]. Furthermore, some polyphenols are known to activate anti-inflammatory response via, inactivation of NF-kB transcription factor, and activation of the PPAR-alpha transcription factor which are critical to the maintenance of mitochondria activity and ATP system, thus ensuring cell viability $[14,17]$ and organ stability.

Polyphenol-rich green leafy vegetables exert hepatoprotective properties via antioxidant and anti-inflammatory responses thus mitigating ROS or xenobiotics-induced cellular damage or death. The health promoting effect of these plants are attributed to their flavonoid constituents which have demonstrated potent modulatory effect on several cellular and molecular events. Flavonoids are a class of polyphenol compounds widely distributed in plant foods with therapeutic effects on liver injuries via complicated mechanisms. They produce subtle effects on multiple targets, and possess a variety of pharmacological activities on oxidative stress, lipid metabolism, insulin resistance, and inflammation; which are important pathological processes underlying tissue damage [21] or xenobiotic-induced organ toxicity.

\section{Conclusion}

Taken together, the results of this study showed that sodium benzoate intoxication could cause hepato-renal dysfunction which is characterized by altered biochemical and molecular indices, compromised cellular and structural integrity, as well as physiological functions of both the liver and kidney. Nevertheless, treatment with methanolic leaf extract of $J$. tanjorensis significantly reversed these anomalies, suggesting its protective effect against sodium benzoate-induced hepato-renal damage, and may be relevant in the prevention/management of some xenobiotic-induced tissue damage or diseases.

\section{Acknowledgements}

The authors appreciate the technical supports of laboratory staff of the Department of Biochemistry, and Mr. Adeleke Opeyemi Samson of the Department of Anatomy, Osun State University, Osogbo, Nigeria.

\section{Authors' contributions}

OJO, OTO and OIO conceptualized and designed the study. OOA, OJO and OTO carried out the experiments and data generation. OJO, AOA and OMO were responsible for statistical analysis and interpretation of the data generated. OJO, OTO, OOA, AOA, OMO and OIO contributed equally to the writing and preparation of the manuscript. The authors read and approved the final manuscript.

\section{Funding}

The authors declare that this research did not receive any specific grant from funding agencies in the public, commercial, or not-for-profit sectors.

\section{Availability of data and materials}

The datasets used and/or analyzed during the current study are available from the corresponding author on reasonable request.

\section{Ethics approval and consent to participate}

The authors declared that the study was approved by the Institution's Ethical Committee and in accordance with the Helsinki Declaration of 1975 as revised in 2000. The animals were kept according to the $\mathrm{NIH}$ guide for the care and use of experimental animals.

\section{Consent for publication}

Not Applicable.

\section{Competing interests}

The authors declare that they have no competing interests.

\section{Author details}

${ }^{1}$ Department of Chemical Sciences, Faculty of Science, Kings University, Ode-Omu, Nigeria. ${ }^{2}$ Phytomedicine and Toxicology Laboratories, Department of Biochemistry, Faculty of Basic and Applied Sciences, Osun State University, Osogbo, Nigeria. ${ }^{3}$ Department of Biochemistry, Functional Foods and Nutraceuticals Unit, Federal University of Technology, Akure, Nigeria.

Received: 16 October 2019 Accepted: 26 February 2020

Published online: 02 March 2020

\section{References}

1. Atansuyi K, Ibukun EO, Ogunmoyole T. Antioxidant properties of free and bound phenolic extract of the leaves of Jatropha tanjorensis in vitro. J Med Plants Res. 2012;6(31):4667-74.

2. Baldwin EA, Nisperos-Carriedo MO, Baker RA. Use of edible coatings to preserve quality of lightly (and slightly) processed products. Crit Rev Food Sci Nutr. 1995:35(6):509-24.

3. Bard JS. The kidney: from normal development to congenital disease. Boston: Academic Press; 2003. p. 154

4. Barrera C, Valenzuela R, Rincon MA, Espinosa A, Echeverria F, Romero N, Gonzalez-Manan D, Videla LA. Molecular mechanisms related to the hepatoprotective effects of antioxidant-rich extra virgin olive oil supplementation in rats subjected to short-term iron administration. Free Radic Biol Med. 2018;126:313-21.

5. Brain Rl, Kay KO. Kidney phosphatase II: the enzyme in disease. Biochem J. 1927:21:1103-4.

6. Cameron JS, Greger R. Renal function and testing of function. In: Davison AM, Cameron JS, Grunfeld JP, Kerr DNS, Rits E, Winearl GC, editors. Oxford textbook of Clinical Nephrology; 1998. p. 36-9.

7. Chalasani N, Aljadhey H, Kesterson J, Murray MD, Hall SD. Patients with elevated liver enzymes are not act high risk for statin hepatotoxicity. Gastroentero. 2004;126:1287-92.

8. Cheesbrough M. Medical laboratory manual for tropical countries. Vol 11. 2nd ed. Cambridge: ELSB; 1991. p. 508-11.

9. Cheesbrough M. Measurement of serum or plasma creatinine and urea. In: District laboratory practice in tropical countries. 2nd ed. Cambridge: Cambridge University Press; 2005. p. 333-40.

10. Chen M, Long Z, Wang Y, Liu J, Pian H, Wang L, Chen Z. Protective effects of saponin on a hypertension target organ in spontaneously hypertensive rats. Exp Ther Med. 2013;5(2):429-32.

11. Chipley JR. Sodium benzoate and benzoic acid. In: Branen AL, Davidson PM, editors. Antimicrobials in foods. New York: M. Decker; 1983. p. 11-35.

12. Dong L, Luo Q, Cheng LZ, Yan YM, Cheng YX, Wang SM. New terpenoids from Resina Commiphora. Fitoterapia. 2017:117:147-53.

13. Duke JA. CRC handbook of medicinal herbs. Boca Raton: CRC Press; 1988. p. 253-4

14. Echeverría F, Valenzuela R, Bustamante A, Alvarez D, Ortiz M, Espinosa A, Illesca P, Gonzalez-Manan D, Videla LA. High-fat diet induces mouse liver steatosis with a concomitant decline in energy metabolism: attenuation by eicosapentaenoic acid (EPA) or hydroxytyrosol (HT) supplementation and the additive effects upon EPA and HT co-administration. Food Funct. 2019;10:6170-83.

15. Félix Vargas $F$, Romecín $P$, García-Guillén Al, Wangesteen $R$, Vargas-Tendero P, Paredes MD, Atucha NM, García-Estañ J. Flavonoids in kidney health and disease. Front Physiol. 2018:9:394

16. Harborne JB. Phytochemical methods. London: Chapman and Hall Limited; 1973. p. 49-88.

17. Hernández-Rodas MC, Valenzuela R, Echeverría F, Rincon-Cervera MA, Espinosa A, Illesca P, Munoz P, Corbari A, Romero N, Gonzalez-Manan D, Videla LA. Supplementation with Docosahexaenoic acid and extra virgin olive oil prevents liver Steatosis induced by a high-fat diet in mice through PPAR- $a$ and Nrf2 Upregulation with concomitant SREBP-1c and NF-kB Downregulation. Mol Nutr Food Res. 2017;61(12):1700479. 
18. lio M, Ushijima K, Fujita M, Matsuura M, Miyatake S. Effect of flavonoids on alkaline phosphatase. Nippon Nōgeikagaku Kaishi. 1980;54(3):171-5.

19. Illesca P, Valenzuela R, Espinosa A, Echeverria F, Soto-Alarcon S, Ortiz M, Videla LA. Hydroxytyrosol supplementation ameliorates the metabolic disturbances in white adipose tissue from mice fed a high-fat diet through recovery of transcription factors Nrf2, SREBP-1C, PPAR- $\gamma$ and NF-kB. Biomed Pharmacother. 2019;109:2472-81.

20. Iwalewa EO, Adewumi CO, Omisore NO, Adebanji OA, Azike CK. Pro- and antioxidant effects and Cytoprotective potentials of nine edible vegetables in Southwest Nigeria. J Med Food. 2005;8:539-44.

21. Li S, Tan HY, Wang N, Cheung F, Hong M, Feng F. The potential and action mechanism of polyphenols in the treatment of liver diseases. Oxidative Med Cell Longev. 2018;2018(8394818):25.

22. Lowry OH, Rosebrough NJ, Farr AL, Randall RJ. Protein measurement with the Folin phenol reagent. J Biol Chem. 1951:193:265-75.

23. Meda A, Lamien CE, Romito M, Millogo J, Andnacoulma OG. Determination of the total phenolic, flavonoid and proline contents in Burkina Fasan honey, as well as their radical scavenging activity. Food Chem. 2005;91:571-7.

24. Mokady IC, Abramovici A, Cogan U. The safety evaluation of dunaviela bardawilla as a potential food supplements. Food Chem Toxicol. 1989;27:221-6.

25. Murray RK, Granner PA, Mayer PA, Rodwell WW. Harper's biochemistry. 20th ed. England: McGraw-Hill; 2000. p. 594-602.

26. Olayiwola G, Iwalewa EO, Omobuwajo OR, Adeniyi AA, Verspohi EJ. The antidiabetic potential of Jatropha tanjorensis leaves. Nig J Nat Prod Med. 2004;8:55-8

27. Omobuwajo OR, Alade GO, Akanmu MA, Obuotor EM, Osasan SA. Microscopic and toxicity studies on the leaves of J. tanjorensis. Afr. J Pharm Pharmacol. 2011;5(1):12-7.

28. Orhue ES, Idu M, Ataman JE, Ebite LE. Haematological and Histopathological studies of Jatropha tanjorensis (J.L. Ellis and Soroja) leaves in rabbits. Asian J Biol Sci. 2008;1(2):84-9.

29. Orth SR, Ritz R. The nephritic syndrome. N Engl J Med. 1998;338:1202-11.

30. Oyanagi K, Kuniya Y, Nagao M, Tsuchiyama A, Nakao T. Cytotoxicities of sodium benzoate in primary culture of hepatocytes from adult rat liver. Tohoku J Exp Med. 1987;152(1):47-51.

31. Oyewole IO, Akingbala PF. Phytochemical analysis and Hypolipidemic properties of Jatropha tanjorensis leaf extract. Eur J Med Plants. 2011:1(4):180-5.

32. Oyewole Ol, Oladele JO. Changes in activities of tissues enzymes in rats administered Ficus exasperata leaf extract. Int J Biol Chem Sci. 2017;11:378-86.

33. Oyewole OI, Oladipupo OT, Bukola VA. Assessment of renal and hepatic functions in rats administered methanolic leaf extract of Jatropha tanjorensis'. Ann Biol Res. 2012;3(2):837-41.

34. Pongsavee M. Effect of sodium benzoate preservative on micronucleus induction, chromosome break, and Ala40Thr superoxide dismutase gene mutation in lymphocytes. Biomed Res Int. 2015;2015(103512):5.

35. Reitman S, Frankel SA. Colorimetric method for the determination of serum glutamic oxaloacetate aminotransferase. Am J Clin Pathol. 1957;28:56-63.

36. Singleton $\mathrm{VL}$, Orthofer $\mathrm{R}$, Lamuela-Raventos RM. Analysis of total phenols and other oxidation substrates and antioxidants by means of FolinCioalteau reagent. Methods Enzymol. 1999;299:152-78.

37. Soto-Alarcon SA, Valenzuela R, Valenzuela A, Videla LA. Liver protective effects of extra virgin olive oil: interaction between its chemical composition and the cell-signaling pathways involved in protection. Endocr Metab Immune Disord Drug Targets. 2018;18(1):75-84.

38. Srour R. Benzoic acid and derivatives. In: Srour R, editor. Aromatic intermediates and derivatives. Paris; 1998. p. A.IV.1-A.IV.17..

39. Valenzuela R, Illesca P, Echeverria F, Espinosa A, Rincon-Cervera MA, Ortiz M, Hernandez-Rodas MC, Valenzuela A, Videla LA. Molecular adaptations underlying the beneficial effects of hydroxytyrosol in the pathogenic alterations induced by a high-fat diet in mouse liver: PPAR-a and Nrf2 activation, and NF-KB down-regulation. Food Funct. 2017:8:1526-37.

40. Wright PJ, Plummer DT. The use of urinary enzyme measurement to detect renal damage caused by nephritic compounds. Biochem Pharmacol. 1974;23:65-73.

\section{Publisher's Note}

Springer Nature remains neutral with regard to jurisdictional claims in published maps and institutional affiliations.

\section{Submit your manuscript to a SpringerOpen ${ }^{\circ}$ journal and benefit from:}

- Convenient online submission

- Rigorous peer review

- Open access: articles freely available online

- High visibility within the field

- Retaining the copyright to your article

Submit your next manuscript at $\boldsymbol{\nabla}$ springeropen.com 